\title{
箱形断面柱のかど溶接を部分溶込み溶接とした柱はり接合部の 力学的挙動に関する研究
}

\section{1. 序}

溶接組立箱形断面柱かど溶接の溶接設計に関しては, 柱はり接合部およびその上下の一定範囲は完全溶込み溶 接とし，柱の中間部分は部分溶込み溶接としているのが 一般的である。

しかし，全長にわたって柱かど溶接を部分溶込み溶接 とする溶接設計が可能であるかを検討することは溶接施 工の簡易化，加工工数および溶接量の減少等の面で意味 あると考えられる”。

本研究は，柱かど溶接ののど厚等を実験変数とする一 連の十字形・柱はり接合部実験 ${ }^{2), 31}$ により，柱はり接合 部における柱かど溶接の耐力および変形性状について考 察し，併せて，柱かど溶接の力学的挙動が骨組部分架構 の接合部に及ぼす影響について検討している。

\section{2. 試験体および試験方法}

2.1 試験体

試験体はFig. 1 に示す十字形・柱はり接合部試験体 で柱のサイズは各試験体とも $\square-250 \times 250 \times 25$ に統一 している。採用した実験変数は以下のとおりである。

（i）柱かど溶接のど厚寸法（a）(5 種類）

$\mathrm{F}: 1.0{ }_{c} t_{f}, \mathrm{~A}: 0.75_{c} t_{\rho}, \mathrm{B}: 0.5{ }_{c} t_{\rho}$

$\mathrm{C}: 0.4{ }_{c} t_{f}, \mathrm{D}: 0.2{ }_{c} t_{s}$

ここで， ${ }_{c} t_{f}$ は柱スキンプレートの厚さを意味する。

(ii）ダイアフラムの厚さ $\left({ }_{d} t\right)$ (4 種類)

$32 \mathrm{~mm}, 25 \mathrm{~mm}, 19 \mathrm{~mm}, 9 \mathrm{~mm}$

（iii） 柱とはりの取合い (4 種類)

柱かど溶接の溶接線位置とはり端接合部の位置関係お よび柱とはりの偏心の有無を組み合わせた取合いＩから IV (Fig. 2参照)。

(iv) はりのサイズ (2 種類)

\footnotetext{
*千葉大学 教授・工博

**千葉大学 技官

*** 千葉大学 大学院生

**** 川崎重工 (株) 鉄構・機器事業部 (昭和 63 年 9 月 3 日原稿受理)

$\begin{array}{lllll}\text { 正会員 } & \text { 森 } & \text { 田 } & \text { 耕 } & \text { 次* } \\ \text { 正会員 } & \text { 江 波戸 } & \text { 和 } & \text { 正** } \\ \text { 正会員 } & \text { 舟 } & \text { 橋 } & \text { 明 } & \text { 之*** } \\ \text { 正会員 } & \text { 小 } & \text { 南 } & \text { 忠 } & \text { 義**** } \\ \text { 正会員 } & \text { 里 } & \text { 見 } & \text { 孝 } & \text { 之**** }^{* * *}\end{array}$

$\mathrm{BH}-360 \times 180 \times 12 \times 19, \quad \mathrm{BH}-360 \times 250 \times 12 \times 19$

試験体は上記の実験変数を組み合わせた Table. 1 に 示す 18 体である。試験体名称は（i）から（iii）まで の実験変数で用いた記号，数値を用いて表し，はりの州 イズに関しては BH- $360 \times 250 \times 12 \times 19$ を用いた試験体 に限り末尾にプライムを付けた。また，実験変数が同一 の試験体が 2 体ある場合は末尾に（1），（2）を付けて 区別した。

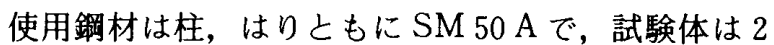
期に分けて製作した。第 1 期の製作はF 32 I から B 32 IIIまでの 12 体である。これらの式験体の溶接は，実施 工を反映して，柱かど溶接は二電極サブマージアーク自 動溶接( V開先, 先行溶接 $6.4 \phi, 1400-1900 \mathrm{~A}, 32-36 \mathrm{~V}$,

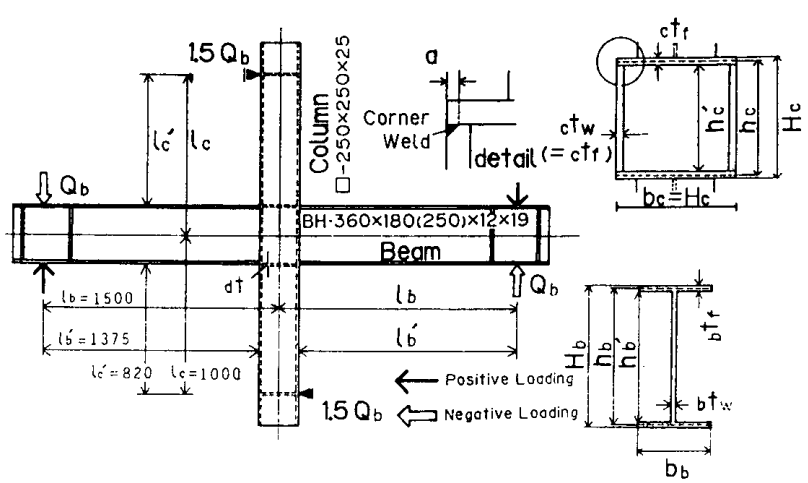

Fig. 1 Geometry of Connection Assemblage Specimen

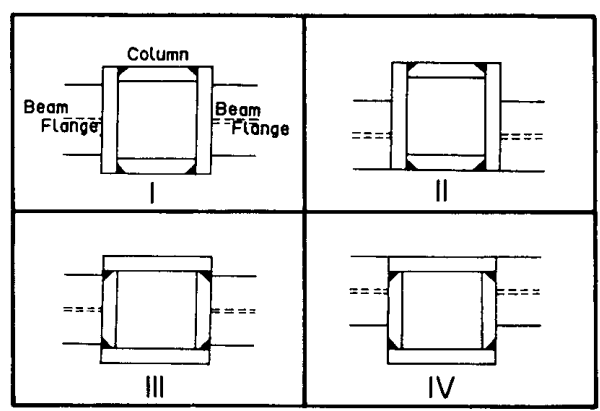

Fig. 2 Layout of Beam Flange to Corner Weld 
$\mathrm{v}=49-66 \mathrm{~cm} / \mathrm{min} .$, 後行溶接 $6.4 \phi, 1000-1200 \mathrm{~A}$, 37-40 V, v=49-66 cm/min. ), 内ダイアフラムは 4 面 とも CES 溶接（I 開先， $3.2 \phi, 380-420 \mathrm{~A}, 36-39 \mathrm{~V}$, $\mathrm{v}=1.5-2 \mathrm{~cm} / \mathrm{min}$.), 柱とはりの溶接は $\mathrm{CO}_{2}$ アーク半 自動溶接（レ開先，1.4 $\phi, 280-350 \mathrm{~A}, 31-35 \mathrm{~V}, \mathrm{v}=$ $15-30 \mathrm{~cm} / \mathrm{min}$.) とした。第 2 期の製作は残りの 6 体で, これら試験体の溶接は柱かど溶接の設計のど厚寸法等を 考虑して，すべて $\mathrm{CO}_{2}$ アーク半自動溶接とした。各試 験体の柱かど溶接のど厚寸法の実測値を Table. 1 に示 し，使用鋼材および全溶着金属の機械的性質を試験体の 製作時期で分類して Table. 2 に示した。

\section{2 試験方法}

柱の両端をローラー支持し，はりの両端にアクチュ エーター 2 基（能力：士100 tf， $\pm 150 \mathrm{~mm}$ ）を用いて逆 対称荷重 $\left(Q_{b}\right)$ を加えた。なお，柱軸力は導入されて いない (Fig. 1 参照)。載荷は正負繰り返し載荷とし, 各サイクルごとに変位振幅を漸増させた。ただし，A $19 \mathrm{I}$ （2）は $Q_{b}= \pm 25 \mathrm{tf}$ で 3 サイクル， $Q_{b}= \pm 38 \mathrm{tf}$ で 6 サイクル, $Q_{b}= \pm 45 \mathrm{tf}$ で 3 サイクル載荷した後に変 位振幅を漸増させた。また，A 19 III は $Q_{b}= \pm 32 \mathrm{tf}$ で 3 サイクル， $Q_{b}= \pm 38 \mathrm{tf}$ で 3 サイクル， $Q_{b}= \pm 46 \mathrm{tf}$ で 10 サイクル載荷して破壊に至らしめた。

\section{3. 実験結果}

\section{1 各試験体の力学的挙動}

試験体のはり端に加えた荷重 $\left(Q_{b}\right)$ と柱端で支持し た治具を用いて測定した全体変形 $\left(\delta_{T}\right)$ の関係 $\left(Q_{b}-\delta_{T}\right.$ 曲線), 接合部パネルのせん断変形角 $(\gamma)$ の関係 $\left(Q_{b}-\gamma\right.$ 曲線)，および二軸クリップゲージ (ゲージ間隔 $50 \mathrm{~mm}$ ) を用いて测定した接合部パネル内の柱かど溶接のせん断 変形 $\left(\delta_{w}\right)$ の関係 $\left(Q_{b}-\delta_{w}\right.$ 曲線) の代表例を Fig. 3 に 示す。また, 正負繰り返し載荷実験により得られた履歴 ループから試験体の各種耐力および変形性状を大づかみ することを目的として，Fig. 4 に示す累加経験則 ${ }^{4}$ に基 ういて求めた各試験体の荷重 $\left(Q_{b}\right)$ と累積変形 $\left({ }_{a} \delta_{T}\right.$, ${ }_{a} \gamma$ および $\left.{ }_{a} \delta_{w}\right)$ の関係を Fig. 5 に示す。

これらの荷重一累積変形関係より求めた骨組部分架構 の降伏耐力 $\left({ }_{T} Q_{y}\right)$ および全塑性耐力 $\left({ }_{T} Q_{p}\right)$, 接合部パ

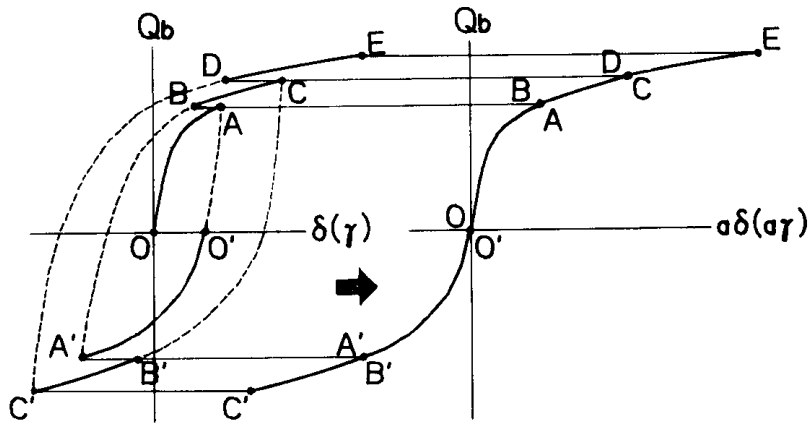

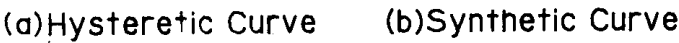

Fig. 4 Relation Between Hysteretic Curve and Synthetic Curve
Table 1 Test Results of Connection Assemblage Specimens

\begin{tabular}{|c|c|c|c|c|c|c|c|c|c|c|c|}
\hline & \multirow{2}{*}{$\begin{array}{c}\mathrm{d} \\
(\mathrm{mm}) \\
\end{array}$} & Yield Strength & \multicolumn{2}{|c|}{$\begin{array}{l}\text { General Yield } \\
\text { Strength }\end{array}$} & \multicolumn{2}{|c|}{$\begin{array}{l}\text { Maximum } \\
\text { Strength }\end{array}$} & \multicolumn{3}{|c|}{ Ductility Factor } & \multirow{2}{*}{ F.M. } \\
\hline & & & TQy $p Q y \quad w Q y$ & $T O p \quad p Q p$ & $w Q p$ & $\mathrm{eQm}$ & wQm & $T^{\mu}$ & $p^{\mu}$ & $w \mu$ & \\
\hline \multirow{12}{*}{$\begin{array}{l}\tilde{n} \\
\vdots \\
\vdots \\
\sim \\
\tilde{n} \\
\sim\end{array}$} & F 32I & 一 & $\begin{array}{llll}31.5 & 30.0 & 32.5 \\
34.1 & 29.3 & 31.5 \\
\end{array}$ & $\begin{array}{ll}38.3 & 36.4 \\
39.8 & 36.8 \\
\end{array}$ & $\begin{array}{l}38.5 \\
39.5 \\
\end{array}$ & 50.00 & & 6.8 & $(15.5)$ & $(13.1)$ & (a) \\
\hline & F19I & - & $\begin{array}{lll}31.5 & 31.5 & 30.0 \\
32.6 & 30.0 & 28.0 \\
\end{array}$ & 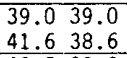 & $\begin{array}{l}40.0 \\
43.0 \\
\end{array}$ & 54.15 & & 11.1 & $(27.7)$ & $(19.8)$ & (a) \\
\hline & A32I & 22.8 & $\begin{array}{ll}33.8 & 32.3 \\
31.1 & 30.0\end{array}$ & 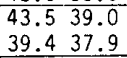 & - & 52.65 & $\longrightarrow$ & 9.4 & $(26.2)$ & 一 & (a) \\
\hline & $A 32 I^{\prime}$ & 23.6 & $\begin{array}{|lll|}34.5 & 33.0 & 33.0 \\
36.0 & 30.5 & 31.0 \\
\end{array}$ & $\begin{array}{ll}42.8 & 40.0 \\
46.5 & 41.3 \\
\end{array}$ & $\begin{array}{l}40.4 \\
39.5 \\
\end{array}$ & $(61.85)$ & 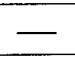 & $(12.0)$ & $(28.6)$ & $(23.0)$ & 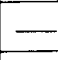 \\
\hline & A32II & 19.0 & $\begin{array}{|lll|}32.3 & 28.5 & 29.0 \\
34.5 & 31.5 & 31.5 \\
\end{array}$ & 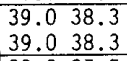 & $\begin{array}{l}39.0 \\
39.5 \\
\end{array}$ & 51.75 & & 8.9 & $(34.0)$ & $(24.9)$ & (a) \\
\hline & A32 I & 19.3 & $\begin{array}{ll}30.8 & 30.8 \\
34.1 & 30.8\end{array}-$ & $\begin{array}{ll}39.8 & 37.5 \\
40.5 & 38.3 \\
\end{array}$ & - & 51.75 & & 8.3 & $(17.8)$ & - & (a) \\
\hline & A25I & 19.5 & $\begin{array}{|lll|}33.4 & 30.0 & 30.0 \\
33.0 & 29.3 & 30.0 \\
\end{array}$ & $\begin{array}{ll}37.5 & 36.4 \\
39.0 & 36.4 \\
\end{array}$ & $\begin{array}{l}36.0 \\
36.3 \\
\end{array}$ & 52.25 & & 8.8 & $(18.0)$ & $(21.1)$ & (a) \\
\hline & $A 19 \mathrm{I}(1)$ & 19.4 & $\begin{array}{|lll|}32.3 & 30.4 & 30.0 \\
32.6 & 30.0 & 30.0 \\
\end{array}$ & $\begin{array}{ll}37.5 & 37.5 \\
39.0 & 37.5 \\
\end{array}$ & $\begin{array}{l}37.0 \\
38.0\end{array}$ & 50.00 & & 7.2 & $(24.2)$ & $(23.3)$ & (a) \\
\hline & A19I (2) & 19.3 & $\begin{array}{|lll|}30.0 & 30.8 & 30.2 \\
31.5 & 29.3 & 27.8 \\
\end{array}$ & $\begin{array}{ll}36.8 & 38.9 \\
38.3 & 36.0 \\
\end{array}$ & $\begin{array}{l}37.1 \\
37.1 \\
\end{array}$ & 50.10 & & 6.1 & $(16.5)$ & $(19.5)$ & (a) \\
\hline & A19 III & 18.2 & $\begin{array}{|lll|}32.6 & 31.5 & 34.9 \\
33.8 & 32.6 & 30.8 \\
\end{array}$ & 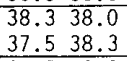 & $\begin{array}{l}39.0 \\
38.3\end{array}$ & 46.05 & & 4.1 & $(8.0)$ & $(21.7)$ & (a) \\
\hline & B32I & 18.9 & $\begin{array}{|lll|}32.3 & 30.0 & 30.0 \\
33.0 & 29.3 & 29.0 \\
\end{array}$ & \begin{tabular}{|ll}
37.5 & 38.3 \\
38.6 & 38.3 \\
\end{tabular} & $\begin{array}{l}38.0 \\
35.5 \\
\end{array}$ & 51.60 & & 9.0 & $(23.1)$ & $(34.0)$ & (a) \\
\hline & B32 III & 12.9 & $\begin{array}{|lll|}33.8 & 30.4 & 33.3 \\
36.0 & 31.5 & 36.3 \\
\end{array}$ & $\begin{array}{|ll|}42.0 & 38.3 \\
40.5 & 39.0 \\
\end{array}$ & - & 51.95 & & 10.3 & $(26.0)$ & & (a) \\
\hline \multirow{6}{*}{ 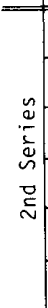 } & C19I & 10.3 & \begin{tabular}{llll|}
32.6 & 32.3 & 28.0 \\
30.0 & 28.5 & 27.5 \\
\end{tabular} & $\begin{array}{l}38.6 \quad 39.0 \\
36.0 \quad 34.9\end{array}$ & $\begin{array}{l}37.0 \\
36.0\end{array}$ & 47.75 & 47.75 & 6.1 & 25.9 & 25.5 & (b) \\
\hline & $032 I^{\prime}$ & 6.0 & $\begin{array}{llll}31.9 & 30.0 & 20.0 \\
31.9 & 29.3 & 14.5 \\
\end{array}$ & $\begin{array}{ll}37.5 & 34.5 \\
38.3 & 33.8 \\
\end{array}$ & $\begin{array}{r}34.0 \\
30.0 \\
\end{array}$ & 46.25 & 41.25 & 7.8 & 11.25 & 18.2 & (c) \\
\hline & D19I & 5.4 & \begin{tabular}{|llll}
32.3 & 30.0 & 20.0 \\
30.0 & 27.8 & 17.5 \\
\end{tabular} & $\begin{array}{ll}34.5 & 36.0 \\
35.3 & 34.9 \\
\end{array}$ & $\begin{array}{l}32.5 \\
29.5 \\
\end{array}$ & 42.75 & 39.95 & 5.6 & 11.6 & 12.8 & (c) \\
\hline & D19 III & 5.6 & $\begin{array}{llll}34.5 & 34.5 & 20.0 \\
30.0 & 28.5 & 24.0 \\
\end{array}$ & $\begin{array}{ll}40.5 & 39.0 \\
36.0 & 35.3 \\
\end{array}$ & $\begin{array}{l}39.0 \\
37.5 \\
\end{array}$ & 48.20 & 46.00 & 6.8 & 15.1 & 8.9 & (b) \\
\hline & $09 \mathrm{I}$ & 6.6 & $\begin{array}{|lll|}30.0 & 28.5 & 20.0 \\
29.4 & 27.4 & 15.5 \\
\end{array}$ & $\begin{array}{lll}33.0 & 35.3 \\
33.0 & 31.9 \\
\end{array}$ & $\begin{array}{l}32.0 \\
28.7 \\
\end{array}$ & 40.75 & 40.75 & 3.4 & 4.6 & 6.8 & (d) \\
\hline & D $9 I^{\prime}$ & 6.7 & $\begin{array}{|lll|}31.1 & 27.0 & 19.0 \\
30.0 & 26.3 & 14.5 \\
\end{array}$ & $\begin{array}{lll}34.5 & 31.9 \\
32.3 & 31.5\end{array}$ & $\begin{array}{l}31.5 \\
29.5 \\
\end{array}$ & 38.05 & 37.05 & 3.7 & 4.1 & 7.1 & (d) \\
\hline
\end{tabular}

F.M.;Fracture Mode, a;Actual Throat Thickness

Layout of Beam Flange

Specimen Name(Ex.): C19I Thickness of Diaphragm
Table 2 Mechanical Properties of Materials

\begin{tabular}{|c|c|c|c|c|}
\hline & Y.P. & T.S. & El. \\
\hline 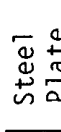 & $\left\{\begin{array}{l}\mathrm{P}-12 \\
\mathrm{P}-19 \\
\mathrm{P}-25 \\
\mathrm{P}-32\end{array}\right.$ & $\begin{array}{l}3.91 \\
3.33 \\
3.87 \\
3.23\end{array}$ & $\begin{array}{l}5.55 \\
5.34 \\
5.35 \\
5.17\end{array}$ & $\begin{array}{l}26.1 \\
27.3 \\
25.9 \\
28.8\end{array}$ \\
\hline \begin{tabular}{l}
$-\stackrel{\circ}{\circ}$ \\
$\bar{\alpha}$ \\
\hdashline
\end{tabular} & $\begin{array}{l}\text { CES } \\
\text { SAW } \\
\text { GAW }\end{array}$ & $\begin{array}{l}3.70 \\
3.34 \\
3.51 \\
\end{array}$ & $\begin{array}{l}4.63 \\
5.09 \\
5.42 \\
\end{array}$ & $\begin{array}{l}38.1 \\
34.9 \\
26.8 \\
\end{array}$ \\
\hline \multicolumn{5}{|c|}{ (b) 2 nd Series } \\
\hline \multicolumn{2}{|c|}{3} & Y.P. & T.S. & El. \\
\hline \multirow[t]{2}{*}{ 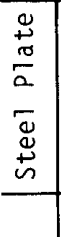 } & $\begin{array}{l}R-9 \\
R-12 \\
R-19 \\
R-19 \star \\
R-25 \\
R-32\end{array}$ & $\begin{array}{l}3.50 \\
3.85 \\
3.38 \\
3.48 \\
3.93 \\
3.89 \\
\end{array}$ & $\begin{array}{l}5.20 \\
5.17 \\
5.42 \\
5.45 \\
5.57 \\
5.48 \\
\end{array}$ & $\begin{array}{l}24.2 \\
26.5 \\
27.3 \\
26.8 \\
25.9 \\
28.9 \\
\end{array}$ \\
\hline & GAW & 4.10 & 5.12 & 35.1 \\
\hline
\end{tabular}

Y.P.; Yield Point $\left(\mathrm{t} f / \mathrm{cm}^{2}\right)$

T.S.; Tensile Strength $\left(t f / \mathrm{cm}^{2}\right)$

CES;Consumable Electro-Slag Welding E1.;Percentage Elongation(\%)

SAW; Tandem Submerged Arc Welding GAW; Gas $\left(\mathrm{CO}_{2}\right)$-Shield Arc Welding 

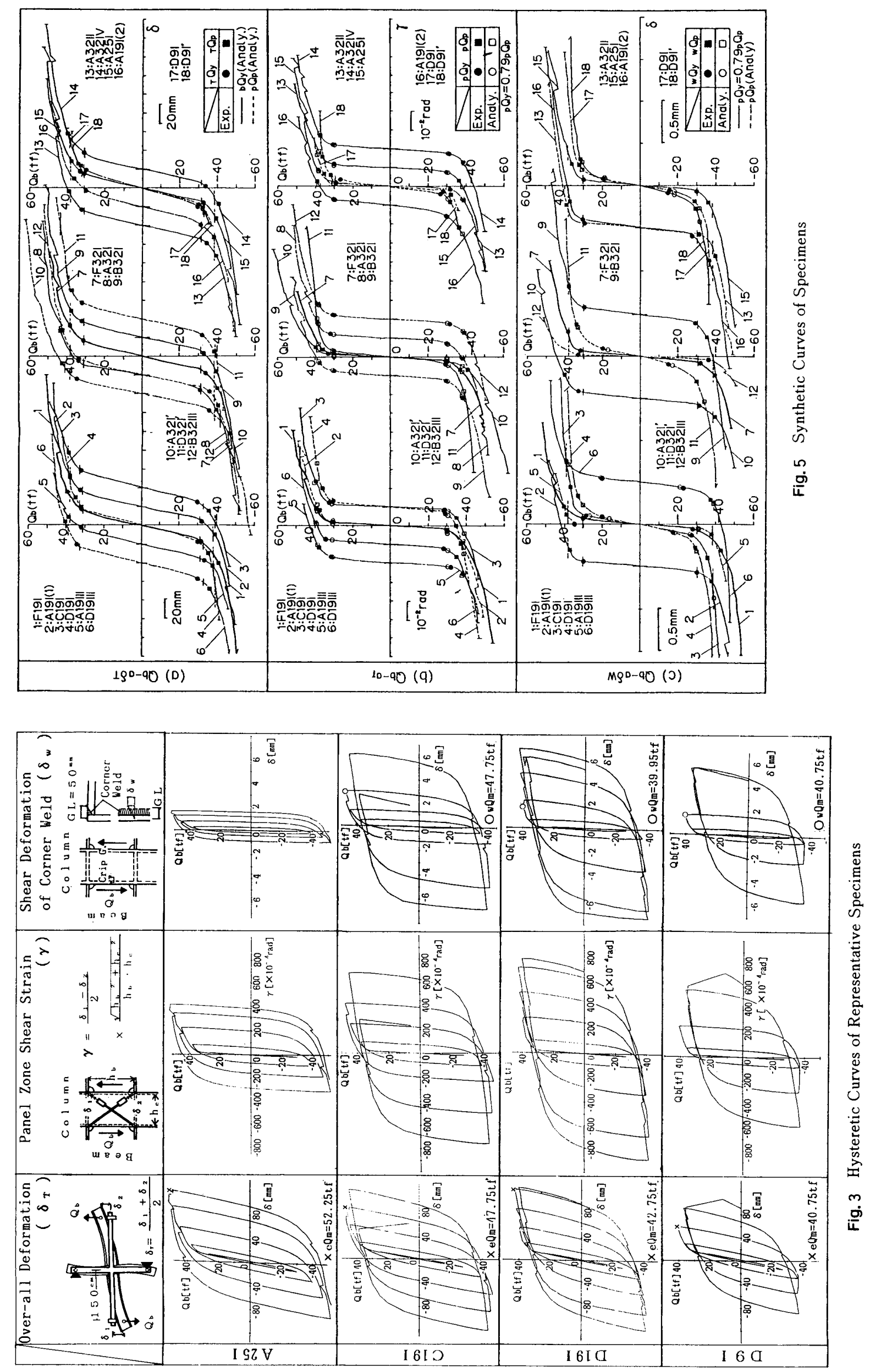
ネルの降伏耐力 $\left({ }_{\rho} Q_{y}\right)$ および全塑性耐力 $\left({ }_{p} Q_{p}\right)$, 柱か よ゙溶接部の降伏耐力 $\left({ }_{w} Q_{y}\right)$ および全塑性耐力 $\left({ }_{w} Q_{\rho}\right)$ をそれぞれ Table. 1 に示す。なお，本実験の載荷方法 では新しい変位振幅には正載荷時より進入する。この影 響も観察できるようTable. 1 には正載荷時の值を上段 に負載荷時の值を下段に示す。ここで, 各部の荷重一累 積変形曲線で初期接線と第 2 折線の交点を降伏変形 ${ }_{a} \delta_{p}\left(a \gamma_{p}\right)$ および全塑性酎力 $\left(Q_{p}\right)$ とし，また，降伏変形 時の荷重を降伏耐力 $\left(Q_{y}\right)$ とした (Fig.6 参照)。なお, Fig. 6 の第 2 折線は荷重一累積変形曲線の ${ }_{a} \delta_{m}\left({ }_{a} \gamma_{m}\right) / 2(こ$ こで, ${ }_{a} \delta_{m}\left({ }_{a} \gamma_{m}\right)$ は試験体各部の最大荷重時での累積変 形量を意味する）における接線である。ただし， $w_{y}$ に 関しては上で定めた降伏耐力ょり早期に $Q_{b^{-}}{ }_{a} \delta_{w}$ 曲線上 で明確な剛性低下を起こす場合はその時の荷重を用い た。

また，各試験体の最大耐力 $\left(e Q_{m}\right)$ ，および，柱かど 溶接に亀裂が生じた試験体に関しては，それまでに経験 した最大の荷重を柱かだ溶接部の最大耐力 $\left({ }_{w} Q_{m}\right)$ と定 義し，その値を同表に示す。

なお,試験体の破壊形式は以下に分類できる(Fig. 7 参 照)。

Type (a)：はり端接合部においてはりフランジが引張 り破断する形式。ただし，この形式は試験体の外観検査 において柱かど溶接に亀裂は観察されないものとする。
Type (b) : 接合部パネル内の柱かビ溶接(1)にせん断亀 裂が観察された後にはり端接合部においてはりフランジ (2)が引張り破断する形式。

Type (c)：接合部パネル内の柱かど溶接(1)にせん断亀 裂が観察された後に接合部パネル内の柱ウェブ(2)がダイ アフラムに沿って曲げ破壊する形式。

Type (d)：接合部パネル内の柱かど溶接(1)に生じたせ ん断亀裂が接合部パネルの外側(2)に進展した後にダイア フラム(3)が張り破断する形式。

各試験体の荷重一累積変形関係により最大塑性率 $\mu=$ $\left.{ }_{a} \delta_{m}\left({ }_{a} \gamma_{m}\right)\right)_{a} \delta_{p}\left({ }_{a} \gamma_{p}\right)$ (Fig. 6 参照) を部分骨組架構 $\left({ }_{r} \mu\right)$, 接合部パネル $\left({ }_{p} \mu\right)$ および柱が゙溶接 $\left({ }_{w} \mu\right)$ について 求めた結果をTable. 1 に示す。ただし，柱かど溶接に 亀裂が生じた試験体に関しては， ${ }_{w} Q_{m}$ での累積最大変 形量を用いて ${ }_{p} \mu, w_{w} \mu$ を求めている。なお, 最大塑性率 は破壊が生じた載荷時についてのみ求め, また, 当該部 分に破壊が生じていない場合はかっこ内に示す。

・試験体各部にてん付したひずみゲージの荷重一累積ひ ずみ関係を用いて求めたひずみ挙動を Fig. 8 に示す。

Fig. 8(a) はダイアフラム近傍における接合部パネルの 柱材軸方向のひずみ分布, (b) は柱フランジ近傍のダ イアフラムのひずみ挙動，(c) ははり端接合部における はりのひずみ分布である。

\section{2 各実験因子の影響}

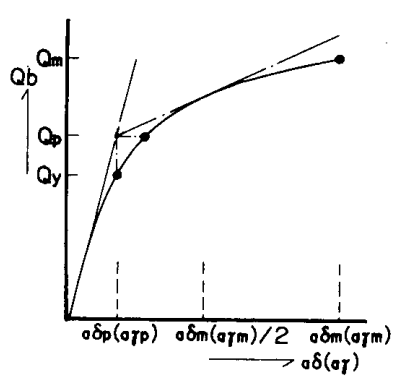

Fig. 6 Definition of Yield Strength $\left(Q_{\boldsymbol{y}}\right)$ and General Yield Strength $\left(Q_{\boldsymbol{D}}\right)$
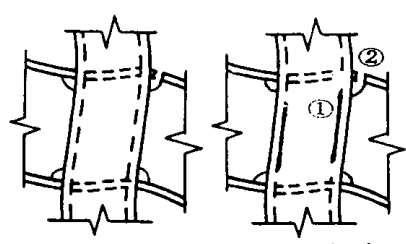

Type (a) Type (b)

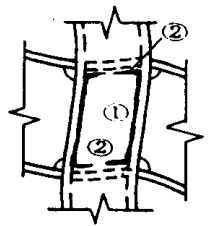

Type (c)

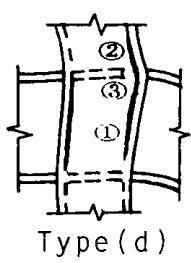

Fig. 7 Fracture Mode of Specimens
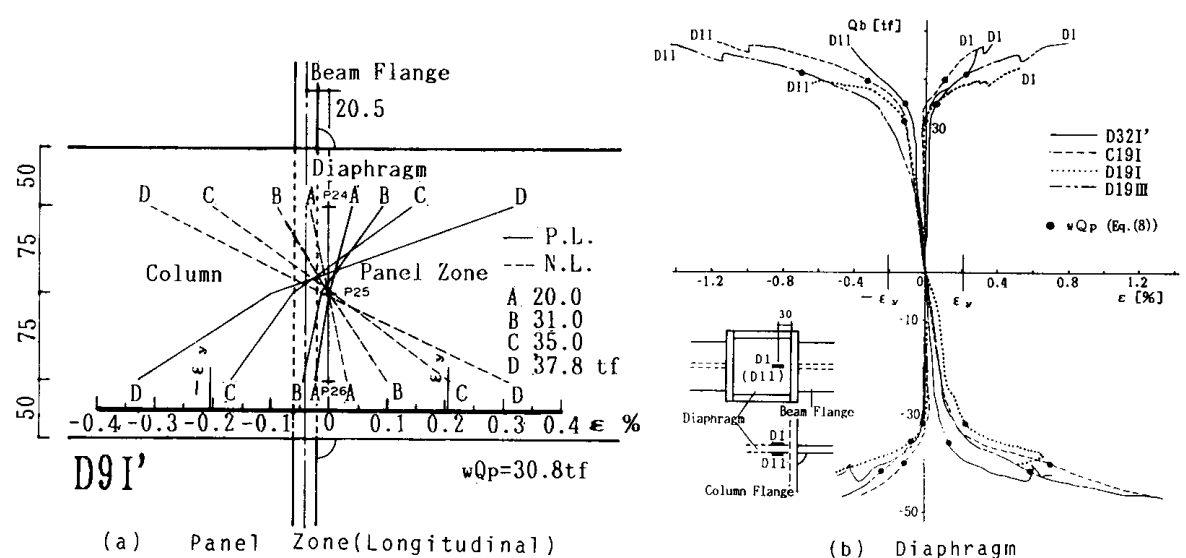

(b) Diaphragin
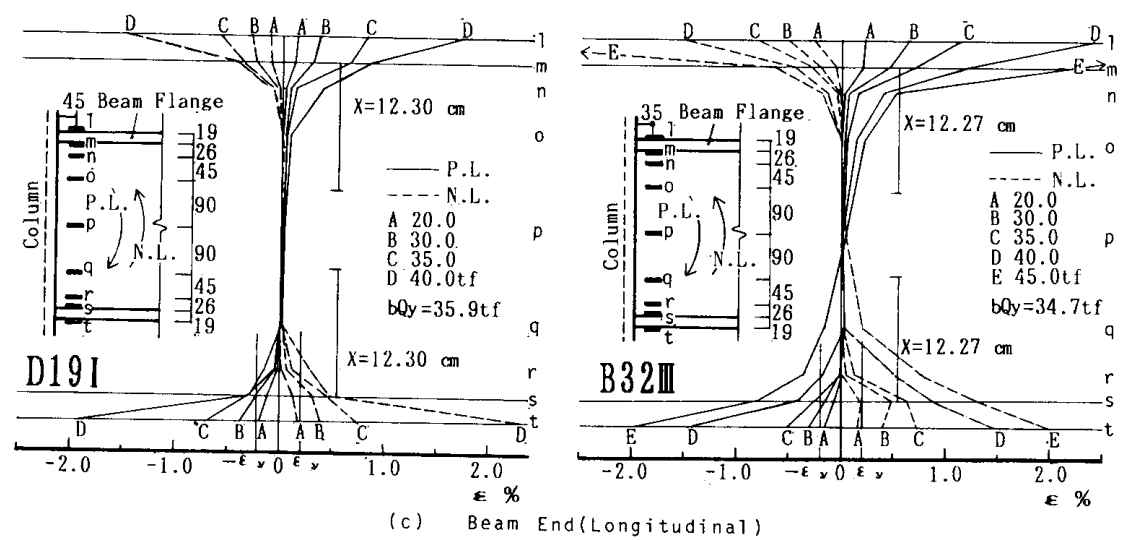

Fig. 8 Strain Distributions in Specimens 


\section{2 .1 柱かど溶接部の耐力および変形能力}

（i）柱かど溶接のど厚寸法 (a)

柱かど溶接部の耐力と a の関係を Fig. 9 に示す。図 ではのど厚寸法以外の変数が同じ試験体を同一シリーズ として扱っている。

${ }_{w} Q_{y}$ は各シリーズともにaとともに大きくなってい る。しかし， $\mathrm{a} \geqq 18.2 \mathrm{~mm}$ では，耐力上昇はわずかであ り, 柱かど溶接が完全溶込み溶接の場合とほぼ同一の值 を示している (Fig.9(a) 参照)。

${ }_{w} Q_{p}$ とa の関係は柱とはりが取合い I では ${ }_{w} Q_{y}$ の場 合と同様な関係を示す。しかし，取合いIII の D 19 III ${ }_{w} Q_{p}$ は，のど厚が $\mathrm{a}=5.6 \mathrm{~mm}$ と小さいにもかかわらず, 柱かど溶接が完全溶込み溶接の試験体と同等の值を示し ている (Fig. 9(b) 参照)。

C $19 \mathrm{I}(\mathrm{a}=10.3 \mathrm{~mm})$ と D $19 \mathrm{I}(\mathrm{a}=5.4 \mathrm{~mm})$ を比較 すると ${ }_{w} Q_{m},{ }_{w} \mu$ は $\mathrm{a}$ とともに大きくなっている。しかし， 柱とはりが取合い I， II の場合では $\mathrm{a} \geqq 18.9 \mathrm{~mm}$ ，取 合いIII，IVの場合では，a $\geqq 12.9 \mathrm{~mm}$ の試験体の最大耐 力は破壊形式 (a) で決定している。

(ii） ダイアフラムの厚さ $\left({ }_{d} t\right)$

柱かど溶接部の耐力 $\left({ }_{w} Q_{p},{ }_{w} Q_{m}\right)$ および最大塑性率 $\left({ }_{w} \mu\right) \sum_{d} t$ の関係をFig. 10 に示す。のど厚が D で柱 とはりの取合いが I の試験体を比較すると，各試験体の $\mathrm{a}$ の実測値を考慮すれば，耐力はわずかに ${ }_{a} t$ とともに 大きくなる傾向があり，また，最大塑性率は ${ }_{a} t$ ととも に大きくなっている。これは，ダイアフラムが柱かど溶 接部の全塑性耐力以後に面外曲げ変形を起こしているこ とと対応していると考えられる (Fig. 8(b) 参照)。また， 試験体の破壊形式も $d t=9 \mathrm{~mm}$ で Type (d)， ${ }_{d} t \geqq 19$ mm で Type (c) と相違している。

(iii）柱とはりの取合い

D 19 I と D 19 III を比較すると，柱かど溶接の耐力お よび最大塑性率は取合いIIIが Iに比較して大きな值を示 す。また，のど厚 $\mathrm{a}$ の実測値はほぼ等しいが柱とはりの 取合いが相違する B 32 I と A 32 II を比較すれば

(Table. 1 参照)，取合いIよIIでは試験体の耐力およ
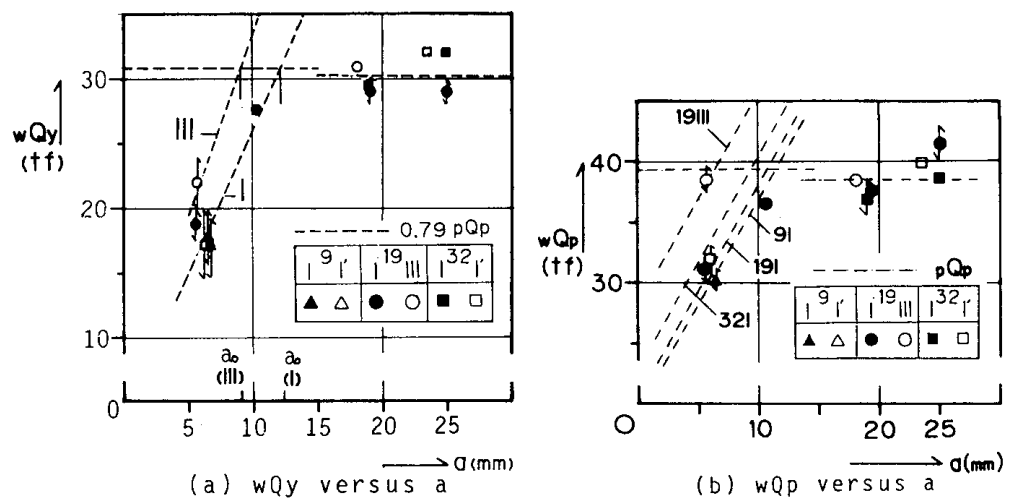

Fig. 9 Variation of Strength of Corner Weld with Throat Thickness
び変形能力に差異が認められない。

（iv）はりのサイズ

柱かど溶接部が破壊した D $9 \mathrm{I}$ と D 9 I'を比較する と，柱かど溶接部の耐力および最大塑性率に差異は認め られないが試験体の最大䩂力は D $9 I^{\prime}$ が D 9 I より若 干小さくなっている。また，柱かど溶接部が破壊してい ないA 32 I とA 32 I' を比較すると, A 32 I' は試験体 の最大耐力が大きくなっている。なお，A 32 I'ははり 端接合部の最大耐力が大きくアクチュエーターのスト ローク制限により実験を中止した。

\section{（v）繰返し載荷の影響}

A 19 I（1）とA19Ｉ（2）とを比較すると試験体の 耐力および変形能力に差異は認められない。なお，繰返 し回数の多いA 19 [II は, ほかの試験体と比較してはり 端接合部の最大耐力は減少しているが，外観検査では柱 かど溶接部に亀裂は観察されていない。したがって，今 回の実験範囲では繰返し回数の相違が柱かど溶接部の耐 力に与える影響は認められないが，繰返し載荷の影響に ついては今後さらに実験資料を蓄積して検討を加える必 要がある。

\section{2 .2 接合部パネルの耐力}

接合部パネルの耐力と柱かど溶接のど厚の関係を Fig. 11 に示す。のど厚が $\mathrm{a} \leqq 10.3 \mathrm{~mm}$ の試験体の耐力 $\left({ }_{\rho} Q_{y}, \rho_{\rho} Q_{p}\right)$ はほ加の試験体と比較して低下する傾向を 示す。これは柱かど溶接のせん断変形の影響と考えられ，

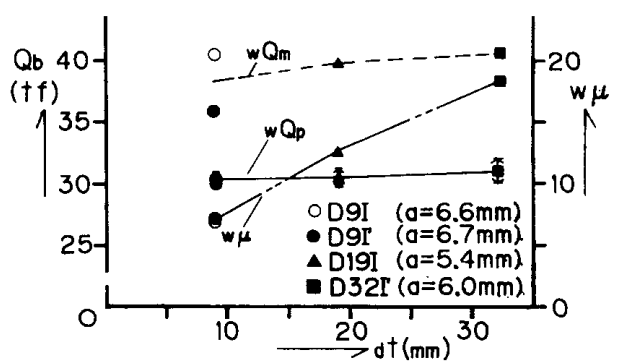

Fig. 10 Variation of Strength and Deformability of Corner Weld with Diaphragm Thickness

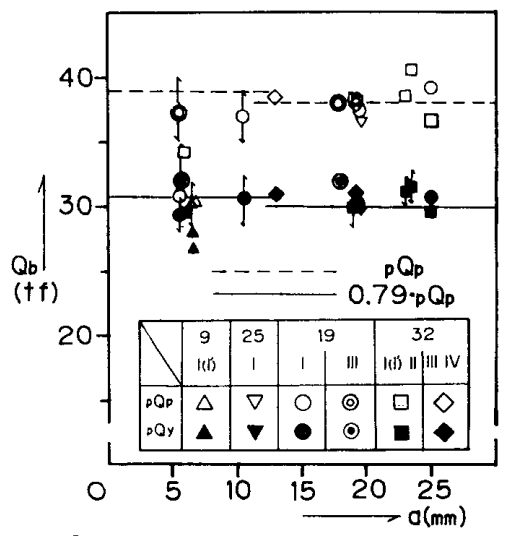

Fig. 11 Variation of Strength of Panel Zone with Throat Thickness 
特にダイアフラムの厚さが薄い場合（D 9 I , D $9 I^{\prime}$ ) に顕著に現れている。

\section{4. 接合部の耐力評価}

4.1 柱かど溶接部のせん断耐力

\section{1 .1 降伏耐力}

接合部パネル両端部でFig. 12 の斜線を施した柱フラ ンジ部分に作用する軸方向力 $N_{f}$ は，柱軸力が作用しな い場合で，柱端が弾性範囲で平面保持の仮定が成立する とすれば，柱とはりの取合いに応じて以下となる。ただ し，記号はFig. 1参照のこと。

（ｉ）柱ウェブ面にかど溶接がある場合（取合いＩ， II )

$$
N_{f}=l_{b} \cdot l_{c}^{\prime} \cdot h_{c} \cdot H_{c} \cdot{ }_{c} t_{f} \cdot Q_{b} /\left(2 l_{c} \cdot I_{c}\right)
$$

ここで， $I_{c}$ ：柱の断面 2 次モーメント

（ii）柱フランジ面にかど溶接のある場合(取合いIII， IV)

$$
N_{f}=l_{b} \cdot l_{c}^{\prime} \cdot h_{c} \cdot h_{c}^{\prime} \cdot{ }_{c} t_{f} \cdot Q_{b} /\left(2 l_{c} \cdot I_{c}\right)
$$

なお，本実験では，柱かど溶接部の降伏時に柱端が塑 性化する試験体は存在しない。

接合部パネル内の柱かど溶接のせん断抵抗により柱 ウェブに伝達される応力 $N_{w}$ は（2）式となる。

$$
N_{w}=2 N_{f}-Q_{b}
$$

柱かど溶接継目のせん断降伏耐力 ${ }_{c} N_{y}$ は, 部分溶込み 溶接継目のせん断降伏応力度を ${ }_{p} \tau_{y}$ とすれば（ 3 ）式と なる。

$$
{ }_{c} N_{y}=2 a \cdot h_{b} \cdot{ }_{p} \tau_{y} \cdot
$$

なお，柱かど溶接が $\mathrm{CO}_{2}$ アーク半自動溶接の場合, $\rho \tau_{y}$ は (4) 式となる (付録参照)。

$$
{ }_{\rho} \tau_{y}=(0.191 / a+1.117)\left({ }_{c} \sigma_{y}+{ }_{a} \sigma_{y}\right) /(2 \sqrt{3})
$$

ここで, ${ }_{c} \sigma_{y}:$ 柱フランジ素材の降伏点

${ }_{a} \sigma_{y}:$ 全溶着金属の降伏点

柱かど溶接部の降伏耐力 ${ }_{w} Q_{y}$ は（2）と（3）式が 等しいとして求められ（5) 式となる。

(i) 取合い I, II ${ }_{w} Q_{y}=2 a \cdot h_{b} \cdot{ }_{\rho} \tau_{y} /\left\{l_{b} \cdot l_{c}^{\prime} \cdot h_{c} \cdot H_{c} \cdot{ }_{c} t_{f} /\left(l_{c} \cdot I_{c}\right)-1\right\}$

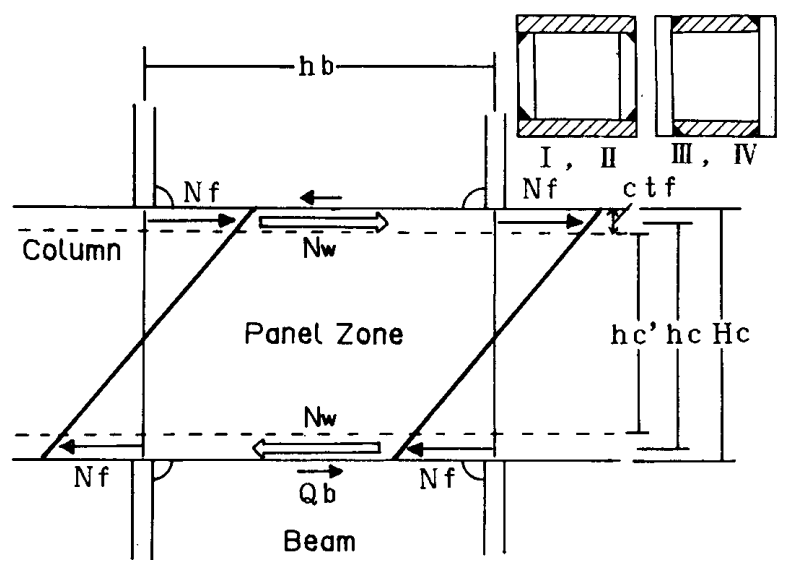

Fig. 12 Analytical Model for Stress Transfer at Yield Strength of Corner Weld

$$
\begin{aligned}
& \text { (ii) 取合いIII, IV } \\
& \left.{ }_{w} Q_{y}=2 a \cdot h_{b}{ }_{\rho} \tau_{y} / \mid l_{b} \cdot l_{c}^{\prime} \cdot h_{c} \cdot h_{c}^{\prime} \cdot{ }_{c} t_{f} /\left(l_{c} \cdot I_{c}\right)-1\right\}
\end{aligned}
$$

\section{1 .2 全塑性耐力}

接合部パネル内の柱かど溶接がせん断降伏を開始する と接合部パネル内の柱ウェブは面内曲げ挙動を示し (Fig. 8(a) 参照)，また，ダイアフラムも柱フランジ 近傍で面外曲げ挙動を示している (Fig. 8(b) 参照)。 したがって, 柱かど溶接部の全塑性耐力時では平面保持 の仮定は成立しないと仮定し，接合部パネル内では Fig. 13(a) に示すとおり，柱かど溶接の部分溶込み溶 接継目はせん断降伏耐力 $\left({ }_{c} N_{y}\right)$, ダイアフラムは柱フラ ンジとの取合い位置で面外方向の全塑性モーメント

$\left({ }_{a} M_{p}\right) ，$ および，2枚の柱ウェブはそれぞれ Fig. 13(b) に示すとおり両端で面内方向の全塑性モーメント $\left({ }_{w} M_{\rho s}\right)$ に達していると仮定する。

柱端の作用モーメントと接合部パネルでの抵抗モーメ ントのつり合いを考えると，柱軸力が作用しない場合，

(6) 式が得られる。

$$
2 M_{e}={ }_{c} N_{y} \cdot h_{c}+4{ }_{w} M_{\rho s}+4{ }_{d} M_{p}+Q_{b} \cdot h_{c}
$$

ここで，左辺の $M_{e}$ は柱端に作用するモーメントで， $M_{e}=l_{b} \cdot l_{c}^{\prime} \cdot Q_{b} / l_{c}$ である。

右辺の第一項は, 接合部パネル内の柱かど溶接の部分 溶込み溶接継目が伝達できる降伏曲げモーメントであ る。
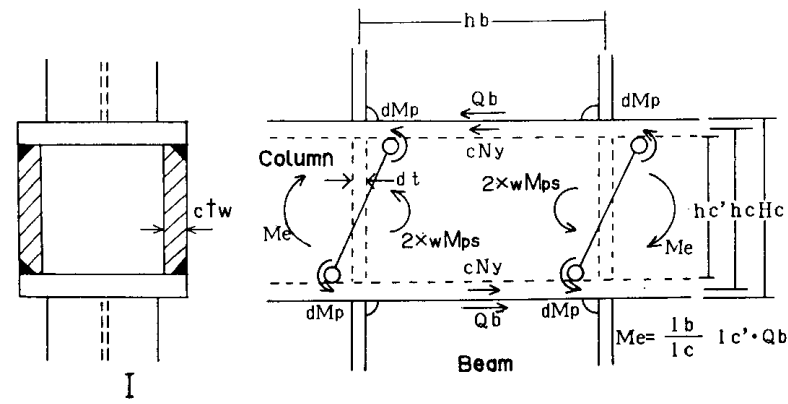

(a) Analytical Model for Stress Transfer

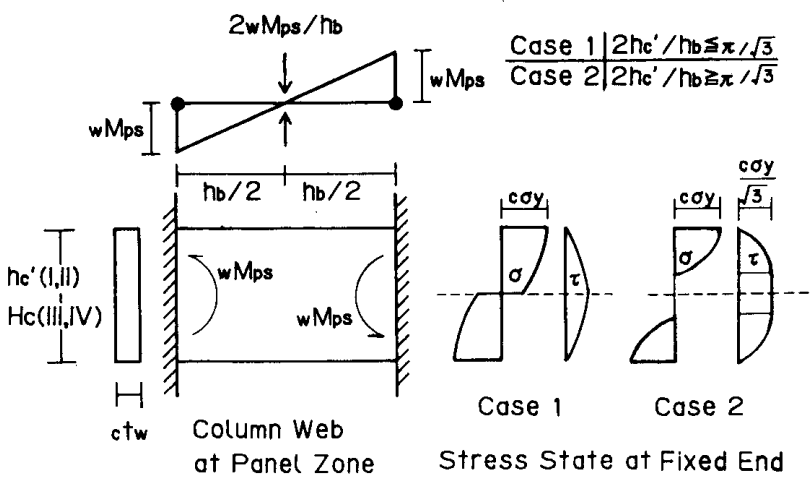

(b) Full Plostic Strength(wMps)of Column Web

Fig. 13 General Yield Strength of Corner Weld 
第二項は，接合部パネル内の柱ウェブの全塑性モーメ ントで，柱ウェブのせい（取合い I， IIでは $h_{c}^{\prime}$ ，取合 いIII，IVでは $\left.H_{c}\right)$ とせん断スパン $\left(h_{b} / 2\right)$ の比が小さ いため，せん断力の影響を考慮している (Fig.13(b) 参照)。 ${ }_{w} M_{p s}$ を取合い I, II について求めると（7）式 となる。

(i) $2 h_{c}^{\prime} / h_{b} \leqq \pi / \sqrt{3}$ の場合 ${ }_{w} M_{p s}=h_{b}^{2} \cdot{ }_{c} t_{w}\left\{1-\cos \left(\sqrt{3} h_{c}^{\prime} / h_{b}\right)\right\}_{c} \sigma_{y} / 6$

ここで, ${ }_{c} \sigma_{y}$ : 柱ウェブ素材の降伏点

(ii ) $2 h_{c}^{\prime} / h_{b} \geqq \pi / \sqrt{3}$ の場合

$$
\begin{aligned}
{ }_{w} M_{p s}= & h_{b} \cdot h_{c}^{\prime} \cdot{ }_{c} t_{w}\left\{1-h_{b}(\pi / 2-1)\right\} \\
& \left.\left(\sqrt{3} h_{c}^{\prime}\right)\right\}_{c} \sigma_{y} /(2 \sqrt{3}) \ldots \ldots \ldots \ldots . . .
\end{aligned}
$$

また, 取合いIII，IVに関しては（7）式中の $h_{c}^{\prime}$ を $H_{c}$ とすれば ${ }_{w} M_{p s}$ は求められる。

なお，本研究における試験体の ${ }_{w} M_{p s}$ は $(7 . \mathrm{a})$ 式に より決まる。

第三項は，ダイアフラムの面外曲げ抵抗で伝達できる 曲げモーメント $\left({ }_{d} M_{p}=h_{c}^{\prime} \cdot{ }_{d} t^{2} \cdot{ }_{d} \sigma_{y} / 4\right.$ ここで, ${ }_{d} \sigma_{y}$ はダ イアフラム素材の降伏点である.) で，第四項は，はり せん断力による抵抗モーメントである。

したがって，柱かど溶接部の全塑性耐力 ${ }_{w} Q_{p}$ は（8) 式となる。

$$
\begin{aligned}
{ }_{w} Q_{\rho}= & l_{c}\left(2 a \cdot h_{b} \cdot h_{c} \cdot{ }_{\rho} \tau_{y}+4{ }_{w} M_{\rho s}+4{ }_{d} M_{\rho}\right) / \\
& \left(2 l_{b} \cdot l_{c}^{\prime}-h_{c} \cdot l_{c}\right) \ldots \ldots \ldots \ldots \ldots \ldots \ldots \ldots \ldots \ldots \ldots \ldots \ldots \ldots \ldots \ldots \ldots \ldots
\end{aligned}
$$

\section{1 .3 最大耐力}

柱かど溶接部の最大耐力時には柱かど溶接の部分溶込
み溶接継目はせん断最大応力度 ${ }_{\rho} \tau_{m}$ となるが，ほかの接 合部パネル部分の構成要素はそれぞれの塑性耐力を維持 するものと仮定する。上記の仮定によれば，柱かど溶接 部の最大耐力 ${ }_{w} Q_{m}$ は, 柱軸力が作用しない場合, (9) 式となる。

$$
\begin{aligned}
{ }_{w} Q_{m}= & l_{c}\left(2 a \cdot h_{b} \cdot h_{c} \cdot{ }_{p} \tau_{m}+4{ }_{w} M_{\rho s}+4{ }_{d} M_{p}\right) / \\
& \left(2 l_{b} \cdot l_{c}^{\prime}-h_{c} \cdot l_{c}\right) \ldots \ldots \ldots \ldots \ldots \ldots \ldots \ldots \ldots \ldots \ldots \ldots \ldots \ldots \ldots \ldots \ldots
\end{aligned}
$$

なお, 柱かど溶接が $\mathrm{CO}_{2}$ アーク半自動溶接の場合, ${ }_{\rho} \tau_{m}$ は (10) 式となる (付録参照)。

$$
{ }_{\rho} \tau_{m}=(0.158 / a+1.017)\left({ }_{c} \sigma_{t}+{ }_{a} \sigma_{t}\right) /(2 \sqrt{3}) \cdots
$$

ここで, ${ }_{c} \sigma_{t}$ : 柱フランジ素材の引張強さ ${ }_{a} \sigma_{t}:$ 全溶着金属の引張強さ

\section{2 はり端接合部の曲げ耐力}

\section{2 .1 降伏曲げ耐力}

柱に箱形断面，はりにH 形断面を用いた柱はり仕口 のはり端接合部の降伏曲げ耐力に関しては柱かど溶接が 完全溶込み溶接の場合についてはその評価方法が提案さ れている21,67,7),8)。本研究では，柱かぼ溶接が完全溶込 み溶接の場合に対して得られた文献 2)，6）に示す降伏 線理論に基づくはり端接合部の降伏曲げ而力の評価法を 柱かど溶接が部分溶込み溶接の場合に対して拡張して適 用する。

解析で用いた主な仮定は以下のとおりである。

（i）柱フランジにはFig. 14(a) に示す降伏線が形 成される。降伏線 $a e\left(a^{\prime} e^{\prime}\right), c f\left(c^{\prime} f^{\prime}\right)$ は柱とはりの 取合いに応じて Fig. 14(a) に示す位置に形成され，そ の単位長さ当たりの全塑性モーメント $M_{a}$ は（11.a) 式

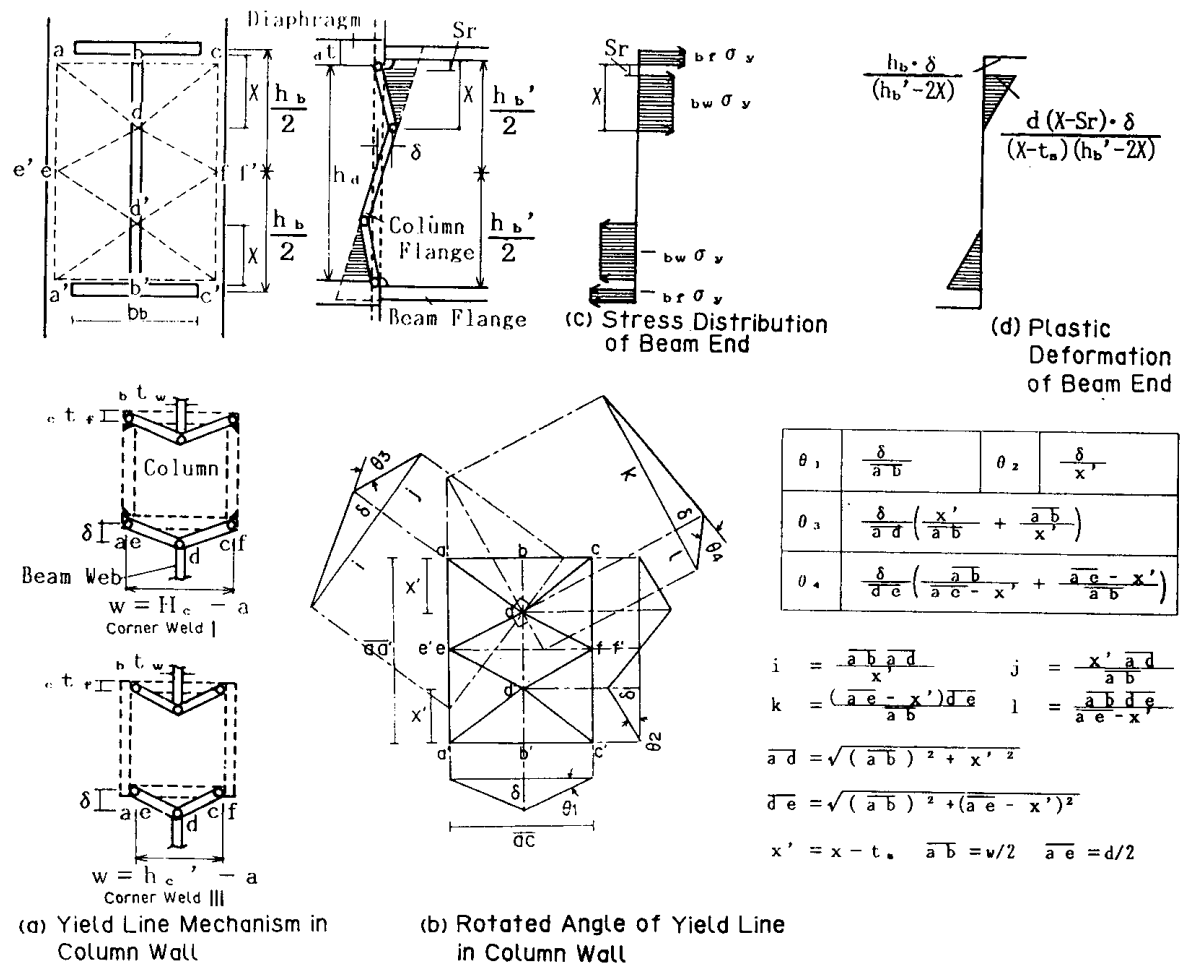

Fig. 14 Yield Line Mechanism of Beam End Joint 
となる。

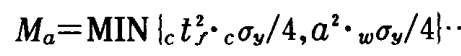

ここで, ${ }_{w} \sigma_{y}=\left({ }_{c} \sigma_{y}+{ }_{a} \sigma_{y}\right) / 2$

その他の降伏線の単位長さ当たりの全塑性モーメント

$M_{0}$ は (11. b) 式である。

$$
M_{0}={ }_{c} t_{\rho}^{2} \cdot{ }_{c} \sigma_{y} / 4
$$

また，柱フランジに形成される降伏線の回転角は降伏 線 $a e\left(a^{\prime} e^{\prime}\right)$ と $c f\left(c^{\prime} f^{\prime}\right)$ に対し $\theta_{1}, a c\left(a^{\prime} c^{\prime}\right)$ に対し $\theta_{2}, a d\left(a^{\prime} d^{\prime}\right)$ と $c d\left(c^{\prime} d^{\prime}\right)$ に対し $\theta_{3}$, および $d e\left(d^{\prime} e^{\prime}\right)$ 之 $d f\left(d^{\prime} f^{\prime}\right)$ に対し $\theta_{4}$ とすれば， $\theta_{1}$ から $\theta_{4}$ は柱芯とは りウェブ芯が一致する場合は Fig. 14（b) に示す值とな る。

(ii) はりウェブはFig. 14(c) は示すとおり， bd 間では引張り降伏し， $b^{\prime} d^{\prime}$ 間では圧縮降伏する。また, $d d^{\prime}$ 区間では無応力状態と仮定する。なお，はりウェブ は Fig. 14(d) に示す変形挙動を示すものとする。

（iii）はりフランジは引張りまたは圧縮降伏してい る。

仮定（i）によれば，柱フランジの内部仕事 ${ }_{c} E_{i}$ は, 柱芯とはりウェブ芯が一致する場合, bd 間の距離を $\mathrm{x}$ とすれば（12）式となる。

$$
\begin{aligned}
& { }_{c} E_{i}=\left\{M_{a}(4 \overline{a e}) \theta_{1}+M_{0}\left(2 \overline{a c} \theta_{2}\right.\right. \\
& \left.+4 \overline{a d} \theta_{3}+4 \overline{d e} \theta_{4}\right) \mid \delta \\
& =4\left[(d / w) M_{a}+\left[w^{2}\left\{d-\left(x-t_{s}\right)\right\}+d\right\} d\right. \\
& \left.-2\left(x-t_{s}\right)\left(x-t_{s}\right)\right] M_{0} /\left[w\left\{d-2\left(x-t_{s}\right)\right\}\right. \\
& \left.\left.\cdot\left(x-t_{s}\right)\right]\right] \delta
\end{aligned}
$$

ここで, $\overline{a e}, \overline{a c}, \overline{a d}, \overline{d e}$ : 線分 $a e, a c, a d, d e$ の長さ

$d=h_{d}, t_{s}=\left({ }_{d} t-{ }_{o} t_{f}\right) / 2$ ただし, ${ }_{o} t_{f} \geqq_{d} t$ の時は $d=$ $h_{d}-\left({ }_{b} t_{f}-{ }_{d} t\right), t_{s}=0$

$w=H_{c}-a\left(\right.$ 取合い I , II ), $h_{c}^{\prime}-a($ 取合い III, IV $)$

なお，記号については Fig. 14 参照のこと。

仮定（ii）によれば，柱フランジに対してはりウェブ 部分のなす外部仕事 ${ }_{b} E_{x}$ は（13）式となる。

$$
\begin{aligned}
{ }_{b} E_{x}= & \left\{d\left(x-S_{r}\right)^{2}{ }_{b} t_{w} \cdot{ }_{b w} \sigma_{y}\right\} \delta / \\
& {\left[\left\{d-2\left(x-t_{s}\right)\right\}\left(x-t_{s}\right)\right] . }
\end{aligned}
$$

$$
\text { ここで, } S_{r}: \text { はりスカラップのサイズ }
$$

$$
{ }_{b w} \sigma_{y}: \text { はりウェブ素材の降伏点 }
$$

$b d$ 区間の距離 $x$ を ${ }_{c} E_{i}={ }_{b} E_{x}$ より求めると, $x$ は (14) 式の解として与えられる。

$$
x=\left(-c_{2}-\sqrt{c_{2}^{2}-4 \cdot c_{1} \cdot c_{3}}\right) /\left(2 c_{1}\right)
$$

$$
\text { ただし， } t_{s}<x<d / 2
$$

ここで,

$$
\begin{aligned}
c_{1}= & -\left\{8\left(M_{a}+M_{0}\right)+w \cdot{ }_{b} t_{w}{ }^{\cdot}{ }_{b w} \sigma_{y}\right\} d \\
c_{2}= & 2\left\{2 d\left(4 t_{s}+d\right)\left(M_{a}+M_{0}\right)-2 w^{2}\right. \\
& \left.\cdot M_{0}+d \cdot w{ }_{b} t_{w} \cdot{ }_{b w} \sigma_{y} \cdot S_{r}\right\} \\
c_{3}= & -4 d \cdot t_{s}\left(2 t_{s}+d\right)\left(M_{a}+M_{0}\right)+4 w^{2} \\
& \cdot\left(t_{s}+d\right) M_{0}-d \cdot w \cdot{ }_{b} t_{w} \cdot{ }_{b w} \sigma_{y} \cdot S_{r}^{2}
\end{aligned}
$$

以上により，はりウェブの降伏域が決定でき，はり端 接合部の降伏曲げモーメント ${ }_{b} M_{y}$ は（15）式となる。

$$
\begin{aligned}
& { }_{b} M_{y}={ }_{b} b \cdot{ }_{b} t_{f} \cdot h_{b} \cdot{ }_{b s} \sigma_{y}+{ }_{b} t_{w}\left(x-S_{r}\right) \\
& \cdot\left(h_{b}^{\prime}-x-S_{r}\right)_{b w} \sigma_{y} \cdot
\end{aligned}
$$

ここで, ${ }_{b j} \sigma_{y}:$ はりフランジ素材の降伏点

\section{2 .2 最大曲げ耐力}

最大曲げ耐力時のはり端接合部の応力状態を Fig. 15 のとおりに仮定する。すなわち，はりの上下フランジは 素材の引張強さに達し，はりウェブは降伏曲げ耐力時の 応力状態を維持する。上記の仮定によれば，はり端接合 部の最大曲げ耐力。 ${ }_{0} M_{m}$ は (16) 式となる。

$$
\begin{aligned}
{ }_{b} M_{m}= & { }_{b} b \cdot{ }_{b} t_{t^{\prime}} \cdot h_{b} \cdot{ }_{b r} \sigma_{t}+{ }_{o} t_{w}\left(x-S_{r}\right) \\
& \cdot\left(h_{b}^{\prime}-x-S_{r}\right)_{b w} \sigma_{y} \cdots \cdots \cdots \cdots \cdots
\end{aligned}
$$

ここで, ${ }_{b f} \sigma_{t}:$ はりフランジ素材の引張強さ

\section{5. 実験結果の考察}

5.1 初期剛性

柱かど溶接が完全溶込み溶接の場合は接合部パネルの 平均せん断応力度 ${ }_{\rho} \tau_{a}$ は（17）式となる。

$$
{ }_{p} \tau_{a}=\left(2 l_{b}^{\prime} / h_{b}-l_{b} / l_{c}\right) Q_{b} /\left(2{ }_{c} t_{w} \cdot h_{c}\right)
$$

したがって, 接合部パネルのせん断変形角 $\gamma$ は (18) 式となる。

$$
\gamma={ }_{\rho} \tau_{a} / G
$$

\section{ここで, $G ：$ 鋼材のせん断弾性係数}

はり端外力 $Q_{0}$ によるはりおよび柱部材の弾性変形を $\delta_{b}, \delta_{c}$ とすれば, 骨組部分架構の全体変形 $\delta_{T}$ は (19) 式となる。なお， $\delta_{b}$ の計算に際し，はりの曲げ剛性に 対するウェブの寄与を無視する ${ }^{61,7) 。 ~}$

$$
\delta_{T}=\left[\delta_{b} / l_{b}+\delta_{c} / l_{c}+\gamma\left\{1-\left(h_{c} / l_{b}+h_{b} / l_{c}\right) / 2\right\}\right] l_{b}
$$

骨組部分架構の初期剛性の実測值は柱かど溶接のど厚 寸法等にかかわらず（19）式による計算値とほぼ一致し ている (Fig. 16(a) 参照)。

接合部パネルの初期剛性の実測値は，D $19 \mathrm{I}$ を除き， （18）式による計算値よりわずかに大きくなっている (Fig. 16(b) 参照)。

5.2 耐力

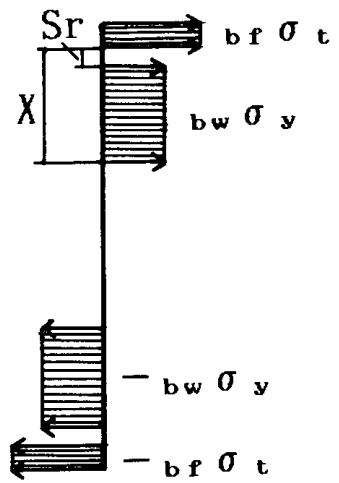

Fig. 15 Stress Distribution of Beam End at Maximum Strength 


\section{2 .1 接合部パネルの耐力}

柱かど溶接が完全溶込み溶接の場合の接合部パネルの 全塑性耐力 $Q_{\rho} Q_{\rho}$ は，(20) 式より求められる。

$$
{ }_{p} \tau_{a}={ }_{c} \sigma_{y} / \sqrt{3}
$$

F 32 I ，F 19 Iについて ${ }_{\rho} Q_{p}$ を計算した結果を Table. 3 およびFig. 5(b) の $Q_{b}-{ }_{a} \gamma$ 曲線に口印で示す。両試験 体の Fig. 6 に示す定義により求めた降伏耐力 ${ }_{\rho} Q_{y}$ は, Fig. 5(b) に示すとおり接合部パネルの剛性低下が始ま る時の荷重と対応し，（20）式による ${ }_{p} Q_{p}$ の計算值の

$\left(0.77\right.$ 0.82) 倍となっている。また， ${ }_{\rho} Q_{p}$ の実験值は 計算値の（0.95〜1.02）倍となっている。

Fig. 11 に $Q_{p}$ の計算値を破線で示すが， $a \geqq 12.9 \mathrm{~mm}$ の試験体については接合部パネルの全塑性耐力は実験変 数の影響が小さいことが分かる。

\section{2 .2 柱かど溶接部のせん断耐力}

(1) 降伏耐力

柱かど溶接部の降伏耐力 ${ }_{w} Q_{\boldsymbol{y}}$ を（5）式により求め た結果をFig.9(a) および Table.4に示す。図では, 計算上で ${ }_{w} Q_{y}={ }_{p} Q_{y}$ となるのど厚を $a_{0}$ としている。た だし，本研究では。 $Q_{y}$ としてF 32 I，F 19 I の実験値 の平均値である $0.79_{p} Q_{p}$ を用いている。 $a \leqq a_{0}$ の試験 体では ${ }_{w} Q_{y}$ の実験値と計算值の比は正載荷時で $0.96 \sim 1.27$ (平均値は 1.10 ), 負載荷時で $0.78 \sim 1.15$ (平 均値は 0.96) となり，正載荷時では計算値は実験値を 若干過少評価しているが両者の対応は比較的良好である と考えられる。しかし， $a>a_{0}$ の試験体では，柱かど溶 接のせん断変形の測定結果に接合部パネルのせん断変形 の影響が大きく現れるため, ${ }_{w} Q_{y}$ の実験值は ${ }_{p} Q_{y}$ で頭打 ちとなっている。

(2) 全塑性酎力

柱かど溶接部の全塑性耐力 ${ }_{w} Q_{p}$ を（8）式より求め

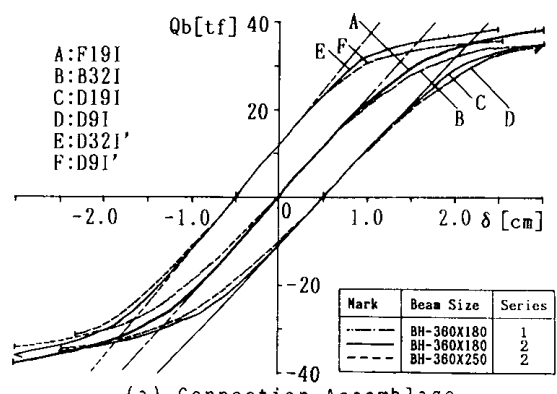

(a) Connection Assemblage

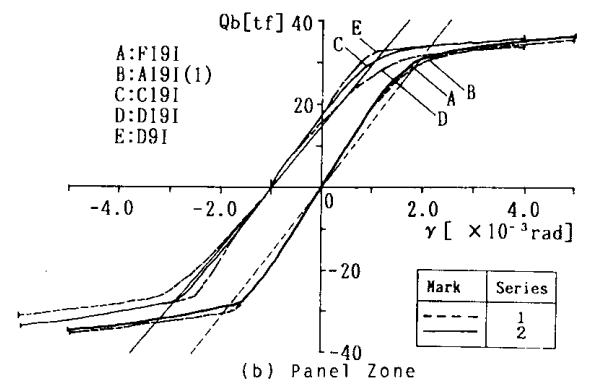

Fig. 16 Initial Stiffness of Specimens
た結果をFig. 9(b) および Table.4に，また，Fig. 5(c) の $Q_{b}-{ }_{a} \delta_{w}$ 曲線に $\square$ 印で示す。

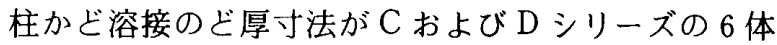
は ${ }_{w} Q_{p} \leqq_{p} Q_{\rho}$ であるが残りの試験体は ${ }_{w} Q_{p}>_{\rho} Q_{p}$ となっ ている (Table.4 参照)。前記の 6 体について ${ }_{w} Q_{\rho}$ の実 験値と計算値の比を求めると正載荷時では $0.96 \sim 1.09$ (平均值は 1.02 ) と両者の対応は良好である。なお, 負載荷時では $0.90 \sim 0.99$ （平均值は $0.94 ）$ 乙計算值は 実験値をわずかに過大評価する傾向があるが，これは実 験值に Bauschinger 効果が現れたためと考えられる。 また，全塑性耐力では，Fig.8(b) に示すとおり，各試 験体ともダイアフラムは面外曲げ挙動を示している。

(3) 最大耐力

柱かど溶接部の最大耐力 ${ }_{w} Q_{m}$ を（9）式より求めた 結果をTable. 4 に示す。柱かど溶接が破断した第 2 期 の試験体について ${ }_{w} Q_{m}$ の実験値と計算值の比は, 1.09 ～1.24（平均值は1.16）となる。計算値は実験値を若 干過少評価しているが, 各実験変数が柱かじ溶接部の最 大耐力に与える影響を比較的良くとらえていると言えよ う。

なお，第 1 期の試験体の ${ }_{w} Q_{m}$ の計算值はすべて ${ }_{w} Q_{m}$ $>_{e} Q_{m}$ となり，これらの試験体の破壊形式がすべて（a) であることと対応している。

なお，第 1 期試験体の柱かど溶接のせん断耐力の解析 に際して， ${ }_{\rho} \tau_{y}$ および ${ }_{p} \tau_{m}$ として（4）および (10) 式 を用いている。しかし，（4）および（10）式が二電極 サブマージアーク自動溶接のような大入熱溶接（86〜 $137 \mathrm{~kJ} / \mathrm{cm})$ に対して成立するかは今後の検討課題であ る。

5.2 .3 はり端接合部の曲げ而力

はりのサイズ BH-360×250×12×19の試験体は柱の

Table 3 Caluculated Strengths of Panel Zone, Column and Beam when Corner Weld is Full Penetration Weld

\begin{tabular}{|c|c|c|c|c|c|c|}
\hline & $\underset{(\mathrm{mm})}{\operatorname{Beam}}$ Size & $\begin{array}{c}p Q p \\
(t f)\end{array}$ & $\begin{array}{r}c Q y \\
(t f)\end{array}$ & $\begin{array}{l}c Q p \\
(t f)\end{array}$ & $\begin{array}{l}\text { boy* } \\
\text { (tf) }\end{array}$ & $\begin{array}{l}\mathrm{bQp} \star \\
\text { (tf) }\end{array}$ \\
\hline 1st Series & $\begin{array}{l}\mathrm{BH}-360 \times 180 \times 12 \times 19 \\
\mathrm{BH}-360 \times 250 \times 12 \times 19\end{array}$ & $\begin{array}{r}38.3 \\
\text { ditto }\end{array}$ & $\begin{array}{l}48.4 \\
\text { ditto }\end{array}$ & $\begin{array}{l}60.0 \\
\text { ditto }\end{array}$ & $\begin{array}{l}31.3 \\
41.7\end{array}$ & $\begin{array}{l}37.1 \\
48.1\end{array}$ \\
\hline 2nd Series & $\begin{array}{l}\mathrm{BH}-360 \times 180 \times 12 \times 19 \\
\mathrm{BH}-360 \times 250 \times 12 \times 19\end{array}$ & $\begin{array}{r}38.9 \\
\text { ditto }\end{array}$ & $\begin{array}{l}49.1 \\
\text { ditto }\end{array}$ & $\begin{array}{l}60.9 \\
\text { ditto }\end{array}$ & $\begin{array}{l}32.7 \\
43.6\end{array}$ & $\begin{array}{l}38.2 \\
49.7\end{array}$ \\
\hline
\end{tabular}

Table 4 Analytical Strengths of Corner Weld

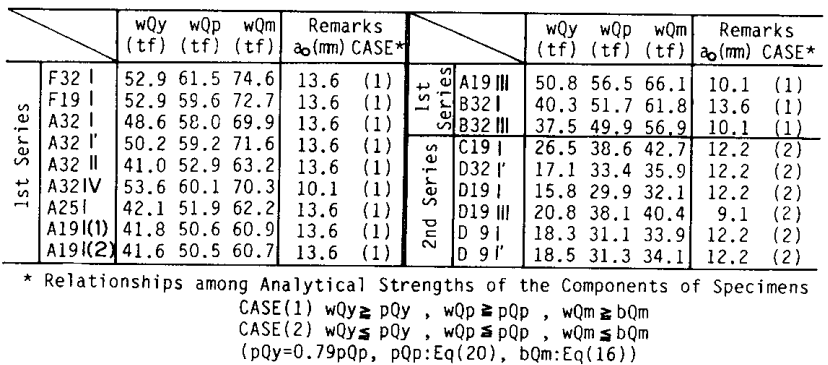


降伏耐力とはりの全塑性耐力が接近しているため, 本節 では，はりのサイズ BH-360×180×12×19の試験体に ついて考察する (Table. 3 参照)。

\section{（1）降伏曲げ耐力}

本研究では，はりの変形を独立した形で測定していな い。そこで, F 19 I, A 19 I ( 1), B 32 I, B 32III, C 19 I, D 19 I, D 19 III について骨組部分架構の全体変 形 (実験値) から接合部パネルのせん断変形 (実験値) および柱の弾性変形（計算値）の寄与を除いて求めたは りの荷重 $\left(Q_{b}\right)$ と変形 $\left({ }_{a} \delta_{b}\right)$ 曲線を Fig. 17 に示す。 同図より，はり端接合部の降伏耐力の実験值を求めた結 果をTable. 5 に示す。

はり端接合部の降伏曲げ耐力 ${ }_{b} Q_{y}={ }_{b} M_{y} / l_{b}^{\prime}$ を（15） 式より求めた結果を Table. 5 に示す。なお，はりウェ ブの塑性化領域 $x$ を(14) 式から求め (Fig.14 参照), その寸法を Fig. 8(c) のはりのひずみ分布図に示す。

${ }_{0} Q_{y}$ の計算値を Fig. 17 に印で示す。計算値は $Q_{b^{-}}{ }_{a} \delta_{b}$ 曲線の降伏曲げ耐力の実験値をわずかに過大評 価するが比較的良く対応していると言える（Table. 5 参 照)。また，降伏曲げ耐力時におけるはりウェブの塑性 化領域 $x$ の解析値は実験における塑性化領域と比較的 良い対応を示している (Fig.8(c) 参照)。

なお，本武験体について。Q $Q_{y}$ と柱かど溶接のど厚寸 法 a および柱とはりの取合いとの関係を（15）式より求

Table 5 Analytical Strengths of Beam End Moment

\begin{tabular}{|c|c|c|c|c|c|}
\hline & \multicolumn{2}{|c|}{ Experimental value } & \multicolumn{2}{|c|}{ Analytical } & \multirow{2}{*}{$\begin{array}{r}\text { value } \\
\text { bQm } \\
(t f)\end{array}$} \\
\hline & $\begin{array}{l}\text { bQy }(t f) \\
\text { P.L. N.L. }\end{array}$ & $\begin{array}{l}\mathrm{bQm} \\
(\mathrm{tf})\end{array}$ & $\begin{array}{c}x \\
(\mathrm{~cm})\end{array}$ & $\begin{array}{r}\text { bQy } \\
(t f) \\
\end{array}$ & \\
\hline F1 & $33.6 \quad 33.0$ & 54.15 & 12.8 & 34.8 & 51.9 \\
\hline & 33.534 .0 & 50.00 & 12.5 & 34.8 & 51.8 \\
\hline B32I & 30.931 .8 & 51.60 & 12.4 & 34.7 & 51.8 \\
\hline B32 III & 30.931 .8 & 51.95 & 12.4 & 34.7 & 51.8 \\
\hline C19 I & 34.034 .0 & & 12.3 & 35.9 & 52.6 \\
\hline D] & $32.4-$ & & 12.3 & 35.9 & 52.6 \\
\hline D19 III & $33.6 \quad 33.6$ & $=$ & 12.3 & 35.9 & 52.6 \\
\hline
\end{tabular}

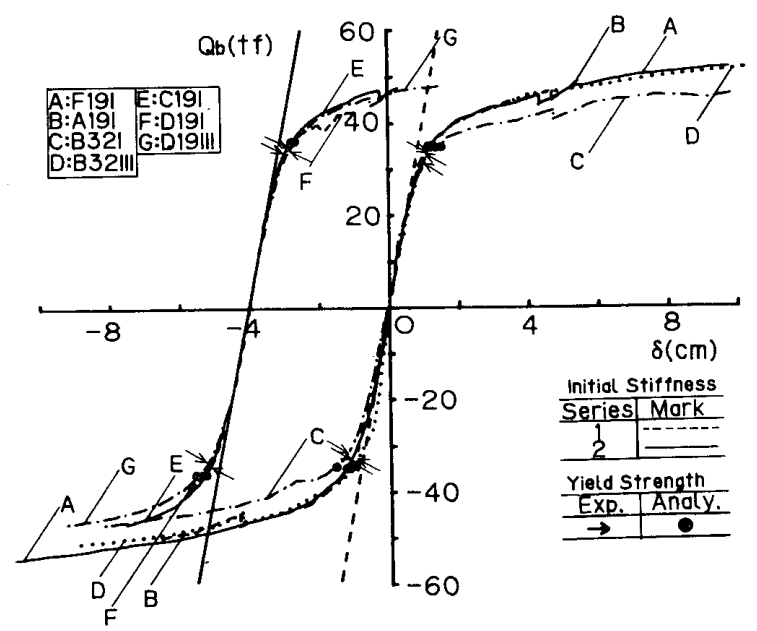

Fig. 17 Synthetic Curves of Beam
め, その結果をFig. 8 に示す。図に見るとおり。蚆に 対するこれら実験因子の影響は比較的小さいと言える。

また, 文献 7）による降伏曲げ耐力の近似解は, 柱か ビ溶接のど厚寸法によらず $35.0 \mathrm{tf}$ (第 1 期試験体), $36.3 \mathrm{tf}$ (第 2 期試験体) となり, 本解析値とほぼ一致し ている。

\section{（2）最大曲げ耐力}

はり端接合部の最大曲げ耐力。 $Q_{m}={ }_{b} M_{m} / l_{b}^{\prime}$ を (16) 式より求めた結果を Table. 5 に示す。

破壊形式が Type（a）の第 1 期試験体（11 体）につ いて ${ }_{b} Q_{m}$ の実験値之計算値の比を求めると $0.89 \sim 1.04$ (平均值 0.99) となり, 両者の対応は良好である。

なお，文献 8）の曲げ耐力推定式では。 $Q_{m}=53.5 \mathrm{tf}$ と なり, 本解析値とほぼ一致している (Table. 5 参照)。

6. まとめ

箱形断面柱かど溶接を部分溶込み溶接とした柱はり接 合部に関する実験結果から得られた主な成果は以下のと おりである。

1）柱かど溶接部のせん断耐力は柱かど溶接のど厚寸 法が大きく,ダイアフラムが厚いほど大きくなる。また, 柱とはりの取合い関係では, 取合い四の方が取合いＩよ り大きな耐力を示す。

2）柱軸力が作用しない場合, 柱かビ溶接部の降伏耐 力は (5) 式, 全塑性耐力は（8) 式, 最大耐力は（9) 式よりほぼ評価できる。

3）はり端接合部の降伏曲げ耐力は（15）式, 最大曲 げ耐力は（16）式よりほぼ評価できる。なお，はり端接 合部の耐力は本試験体では柱かど溶接のど厚寸法, 柱と はりの取合い関係などに大きな影響を受けないことが判 明した。

なお，上記の成果は，柱とはりのサイズが限定され， また, 柱軸力が作用していない試験体の実験結果から得 られたものであり，今後さらに実験資料を蓄積して検討 を加える必要がある。

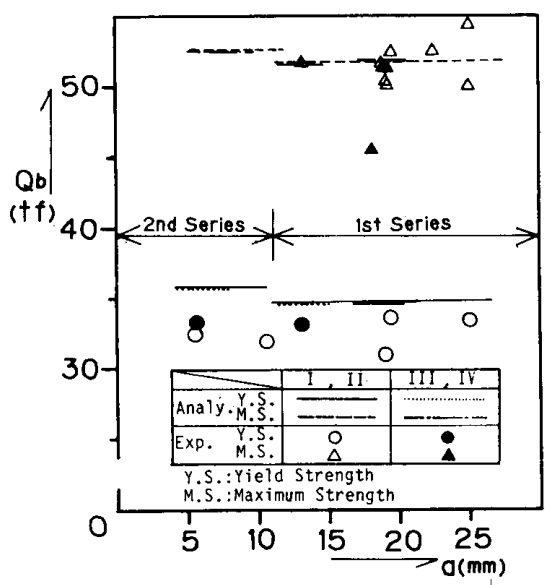

Fig. 18 Relation Between Yield Strength of Beam End and Throat Thickness of Corner Weld 


\section{謝 辞}

実験の実施および資料の整理では，岐皁高專・下村波 基助教授, 千葉大学大学院生・李 在純 (大建設計), 卒論生・関根章義（前田建設工業）・石井 匠および川 崎重工(株)・小坂 裕の諸氏に協力を得ました。ここに， 関係各位に深甚の謝意を表します。

\section{参考文献}

1）森田耕次，江波戸和正，小南忠義，里見孝之，吉村一夫 : 溶接組立箱形断面柱のかど溶接に関する研究一その 1 . 溶接設計及び施工の問題点, 日本建築学会大会学術講演 梗概集 (北海道)，C 構造 II, pp 823-824，昭和 61 年 8 月

2）森田耕次, 江波户和正, 李 在純, 小南忠義, 里見孝之 : 溶接組立箱形断面柱のかど溶接に関する研究一その 2. 実験計画及び実験結果, その3. 実験結果の検討, 同上(近 幾)，C 構造 II, pp 897-900, 昭和 62 年 10 月

3）森田耕次，江波戸和正，舟橋明之，李 在純，小南忠義, 里見孝之, 小坂 裕：溶接組立箱形断面柱のかビ溶接に 関する研究一その 4. 実験（II）の計画及び結果，その 5. 実験（II）の結果の検討, 同上 (関東), C 構造 II, pp $879-882$, 昭和 63 年 10 月

4) Ben Kato : Beam-to-Column Connection Research in JAPAN, Journal of the Structural Division, ASCE, Vol. 108, No. ST 2, February, pp 343-360, 1982

5）田中 尚：構造物の極限解析, 彰国社, pp 120-125, 昭 和 41 年 7 月

6）森田耕次，橋本健一，寺岡 勝，林 和也，安藤鉄也：

Table AP. 1 Test Results of Model Specimens

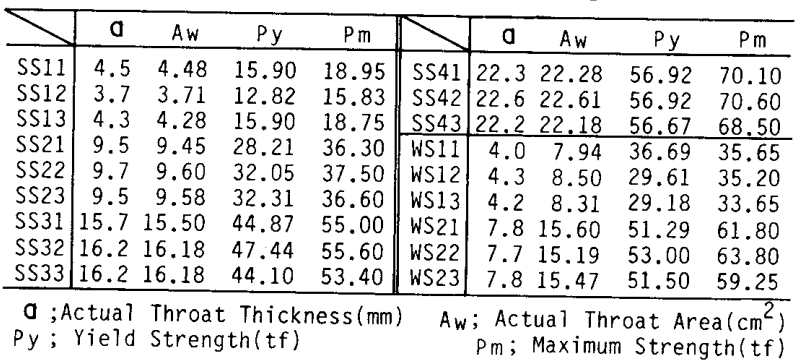

Table AP. 2 Mechanical Properties of Materials

\begin{tabular}{c|ccc}
\hline & $\begin{array}{c}\text { Y.P. } \\
\left(\mathrm{tf} / \mathrm{cm}^{2}\right)\end{array}$ & $\begin{array}{c}\text { T.S. } \\
\left(\mathrm{tf} / \mathrm{cm}^{2}\right)\end{array}$ & $\begin{array}{c}\text { E1. } \\
(\%)\end{array}$ \\
\hline $\mathrm{P}-25$ & 3.87 & 5.35 & 25.9 \\
\hline GAW & 3.51 & 5.42 & 26.8 \\
\hline
\end{tabular}

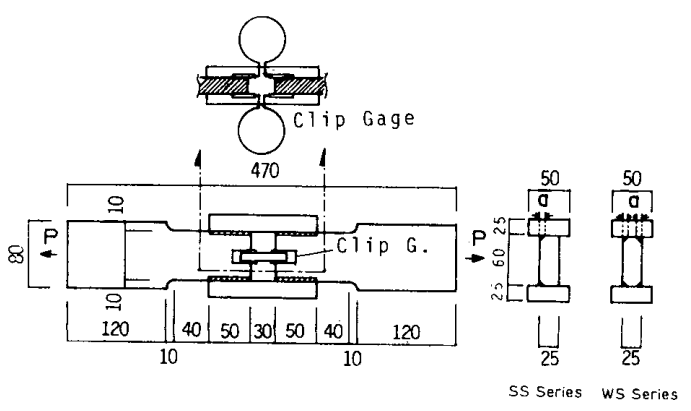

Fig. AP.1 Geometry of Model Specimens for PartialPenetration Weld
鉄筋コンクリート被覆角形鋼管柱鉄骨はり構造に関する 実験的研究, 構造工学論文集, 日本建築学会, Vol. 34 B, pp 237-248, 1988. 3

7）立山英二，井上一朗，杉本正三，松村弘道：通ダイアフ ラム形式で角形鋼管柱に接合される $\mathrm{H}$ 形断面はりの耐力 と変形性能に関する研究一日本建築学会構造系論文報告 集, No. 389, pp 109-121，1988.7

8）田洲基嗣，坂本真一，金谷 弘，藤原勝義，上場輝康： 角形鋼管柱に接合される $\mathrm{H}$ 形断面はり端部の曲げ耐力の 評価一日本建築学会構造系論文報告集, No. $389, p p$ $122-131,1988.7$

\section{付録 部分溶込み溶接継目の耐力}

柱かど溶接に用いられる部分溶込み溶接継目のせん断耐力を 調榃する目的で Fig AP.1に示すモデル試験体の実験を行った。 試験体は片面溶接 (SS) および両面溶接 (WS) の両シリーズで, のビ厚寸法を実験変数として Table AP.1 に示す 18 体とした。 なお，採用した溶接法は $\mathrm{CO}_{2}$ アーク半自動溶接で, 鋼材(SM 50) および全溶着金属の機械的性質を Table AP. 2 に示す。

試験体の荷重 $(P)$ と変形 $(\delta)$ の関係を Fig AP.2 に示す。 ここで，変形は Fig AP. 1 に取付け位置を示すクリップゲージ により測定した。また，実験終了後にのど厚寸法を破断面より 実測した。各試験体の実測のよ゙愿寸法 (a), General yield point 法により求めた継目の降伏耐力 $P_{y}$ (Fig AP.2参照) およ び最大耐力 $P_{m}$ をTable AP. 1 に示す。

継目のせん断降伏応力度 ${ }_{p} \tau_{y}=P_{y} / A_{w}$ (ここで， $A_{w}$ : 継目の ぞ断面積）を付 $1(\mathrm{a})$ 式で表す。

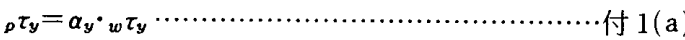

$$
\begin{aligned}
& \text { ここで, }{ }_{w} \tau_{\mathbf{y}}=\left({ }_{c} \sigma_{\mathbf{y}}+{ }_{a} \sigma_{\mathrm{y}}\right) /(2 \sqrt{3}) \cdots \cdots \cdots \cdots \cdots \cdots \cdots \cdots \text { 付 } 1(\mathrm{~b}) \\
& { }_{c} \sigma_{y}: \text { 母材の降伏点 } \\
& { }_{a} \sigma_{y}: \text { 全溶着金属の降伏点 }
\end{aligned}
$$

$\alpha_{y}$ と $a$ の関係は, Fig AP. 3 に示すとおり, SS およびWS
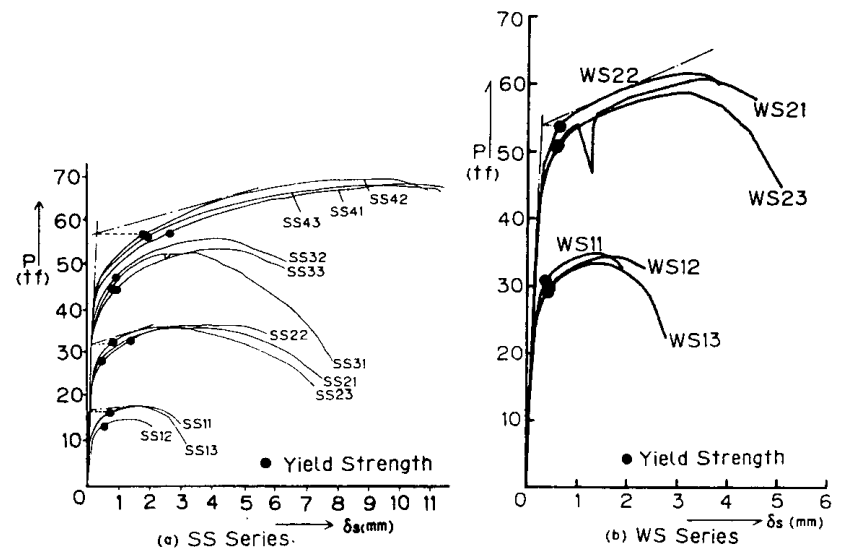

Fig. AP. 2 Load-Deformation Curves of Specimens

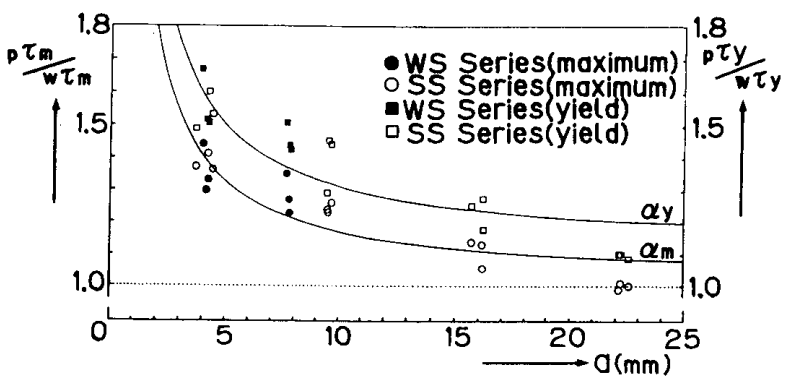

Fig. AP. 3 Relation Between $\alpha_{y}, a_{m}$ and Throat Thickness 
両シリーズに共通した関係が認められ，最小 2 乗法によれば， $\alpha_{y}$ は付 1(c) 式となる。

$$
\alpha_{y}=0.191 / a+1.117
$$

同様にして継目のせん断最大応力度 ${ }_{\rho} \tau_{m}=P_{m} / A_{w}$ を付 $2(\mathrm{a})$ 式で表す。

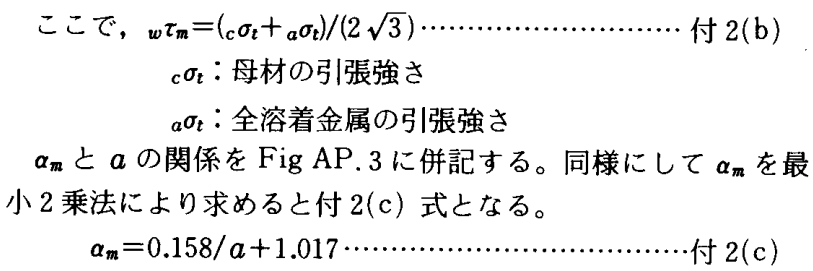

\section{SYNOPSIS}

UDC : 624. $012.2: 621.791 .019: 624.075 .23: 624.072$

\section{STUDY ON STRUCTURAL BEHAVIORS OF BEAM-TO-COLUMN CONNECTIONS -IN CASE CORNER WELD OF BOX COLUMN IS PARTIAL PENETRATION WELD-}

by Dr. KOJI MORITA, Prof. of Chiba Univ., KAZUMASA EBATO, Tech. Engnr. of Chiba Univ., AKIYUKI FUNAHASI, Graduate Student of Chiba Univ., TADAYOSHI KOMINAMI, and TAKAYUKI SATOMI, Kawasaki Heavy Industries, LTD, Members of A.I. J.

Structural behaviors of beam-to-column connections has scarcely been studied when the corner weld of boxcolumn section is partial penetration weld.

In this study, connection assemblage tests have been carried out with variables of throat thickness of corner weld, plate thickness of inner diaphragm, and, layout and size of beam flange. And the conclusions attained are as followings.

1) Maximum shear strength of corner weld at connection panel increases with throat thickness of corner weld and plate thickness of inner diaphragm, and it depends on the layout of beam flange to corner weld.

2) Yield, general yield and maximum strengths of corner weld at connection panel can be estimated by Eq. ( 5 ), ( 8 ) and ( 9 ), respectively.

3) General yield and maximum strengths of beam end joint can be estimated by Eq. (15) and (16), respectively when wide flange beam is welded to box column. And they are almost independent of the throat thickness of corner weld. 